\title{
FOLIATION PATTERN OF GULKANA GLAGIER, ALASKA RANGE, ALASKA
}

\author{
By Nathaniel W. Rutter \\ (Department of Geology, University of Alberta, Edmonton, Alberta, Canada)
}

\begin{abstract}
Gulkana Glacier, consisting of three major ice streams and two prominent ice falls, displays a complex foliation pattern. In the western ice stream, below Gabriel Ice Fall, the foliation is transverse, developing gradually down-glacier into a distinct series of nested arcs. The arcs are concave up-glacier with the foliation dipping steeply toward the inside of the arc. A similar pattern is displayed in the eastern ice stream but there the pattern is less distinct with the arcs evolving into a series of nested semi-arcs. The central ice stream is characterized by vertical layers of foliation with a longitudinal strike. Apparently, longitudinal foliation will form in areas with strong compression and shear caused by differential flow velocity such as where two ice streams unite. The foliation that ultimately displays arcuate (or semi-arcuate) patterns originates principally at the base of an ice fall where strong longitudinal compression is present due
to the decrease of gradient.
\end{abstract}

RÉsumÉ. Foliation dans le Gulkana Glacier, Alaska Range, Alaska. Le Gulkana Glacier, qui comprend trois courants principaux et deux ruptures de pente (ou cascades de glace) remarquables, montre une structure feuilletée complexe. Dans le courant occidental, au-dessous de la "cascade de glace" Gabriel, le feuilletage, primitivement transversal, prend vers l'aval du glacier l'aspect d'un ensemble d'arcs inbriqués les uns dans les autres. Les arcs tournent leurs concavités vers l'amont du glacier, et le feuilletage plonge fortement vers l'intérieur de l'arc. Le courant oriental montre une structure analogue, mais moins distincte; les arcs s'ouvrent pour former plutôt des demi-arcs inbriqués. Le courant central est caractérisé par un feuilletage composé de couches verticales, dont l'allongement est longitudinal. Il semble que ce feuilletage longitudinal se forme dans des régions où règnent de fortes contraintes de compression et de cisaillement dues à des vitesses d'écoulement différentes; par exemple, là ou deux courants se rejoignent. Le feuilletage qui a pour résultat final une structure arquée (ou demi-arquée), a son origine principale à la base d'une rupture de pente, où l'on trouve une forte compression longitudinale due à la baisse du gradient.

Zusammenfassung. Bänderungssysteme am Gulkana Glacier, Alaska Range, Alaska. Der Gulkana Glacier, der aus drei grösseren Eisströmen und zwei ausgeprägten Gletscherbrüchen besteht, zeigt ein kompliziertes Bänderungssystem. Auf dem westlichen Eisstrom unterhalb des Gabriel-Gletscherbruches verläuft die Bänderung quer und entwickelt sich allmählich gletscherabwärts zu einer deutlichen Serie von ineinandergeschachtelten Bögen. Diese Bögen sind nach oben konkav, die Bänderung fällt steil gegen ihre Innenseite ein. Der östliche Eisstrom zeigt ein ähnliches, jedoch weniger deutliches Bild; die Bögen entwickeln sich dort in eine Serie ineinandergeschachtelter Halbbögen. Der mittlere Eisstrom ist durch vertikale Bänderung mit Streichen in der Längsrichtung charakterisiert. Offensichtlich entwickelt sich eine längsgerichtete Bänderung in Gebieten, in denen unterschiedliche Fliessgeschwindigkeiten starken Druck und Scherung hervorrufen, wie dort, wo sich zwei Eisströme vereinigen. Die Bänderung, die schliesslich bogenförmig oder halbbogenförmig verläuft, entsteht hauptsächlich am Fuss von Gletscherbrüchen, wo wegen des geringeren Gefälles starker Druck in der Längsrichtung auftritt.

\section{INTRODUCTION}

Gulkana Glacier (lat. $63^{\circ} \mathrm{I} 3^{\prime}$ N., long. $145^{\circ} 27^{\prime}$ W.) is one of several temperate valley glaciers flowing off the south side of the rugged central Alaska Range. The glacier lies $6 \cdot 4 \mathrm{~km}$. east of the Richardson Highway at Isabelle Pass and about $216 \mathrm{~km}$. south-east of Fairbanks, Alaska (Figs. I and 2).

The accumulation area of Gulkana Glacier is composed of three adjacent compound cirques (Fig. 3). The average elevation of the cirques is $1,980 \mathrm{~m}$. with the highest point of the glacier at approximately $2,225 \mathrm{~m}$. Ice from these three cirques converges at about the firn line into a single south-south-west flowing valley glacier and flows for about $4 \mathrm{~km}$. to an elevation of approximately $\mathrm{I}, \mathrm{I} 90 \mathrm{~m}$. The glacier covers an area of $19.2 \mathrm{~km} .^{2}$. In 1960 , the maximum elevation of the firn line was approximately $1,770 \mathrm{~m}$.

The principal features of Gulkana Glacier are the Gabriel and Moore Ice Falls and three ice streams, numbered I, 2 and 3 ( $a$ and b) from east to west (Fig. 3). Each ice stream is separated by a medial moraine and each is fed from a different compound cirque. In the lower part of the glacier there are a number of parallel medial moraines and longitudinal strips of rock debris (Fig. I). Dimensions of the ice streams are given in Table I. 
Chevron, en échelon, splaying and transverse crevasses are present in various locations on Gulkana Glacier. Weakly defined ogives are displayed immediately below Gabriel Ice Fall in ice stream $3 \mathrm{~b}$. In ice stream I stratification layers can be observed to the east of the rock bastion that separates ice stream 3 into two components ( $3 \mathrm{a}$ and $3 \mathrm{~b}$ ). Thrust faults are present in each ice stream near the terminus of the glacier.

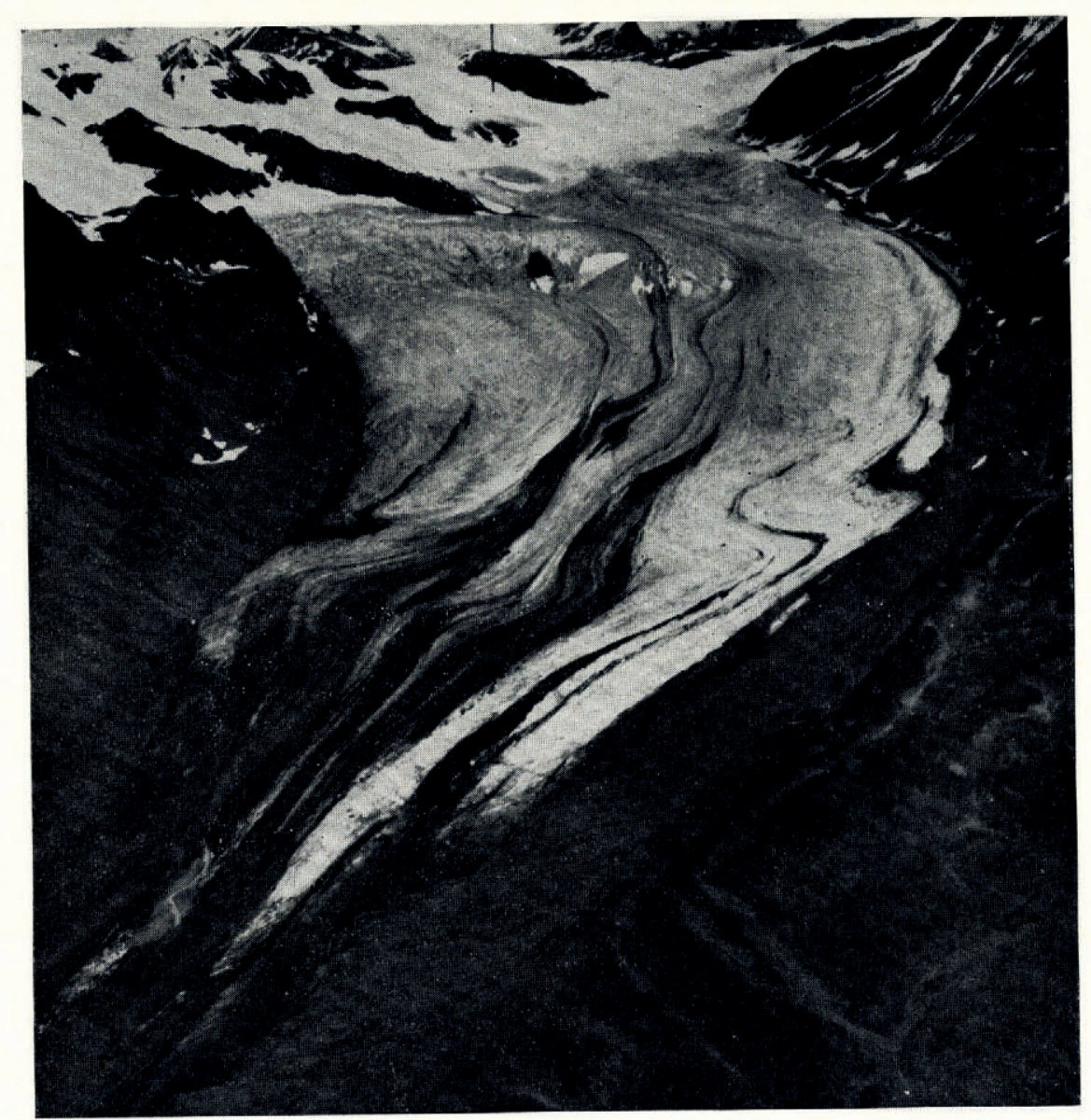

Fig. I. Gulkana Glacier, central Alaska Range, Alaska. View towards north-north-east. (Photograph by Austin S. Post, 22 August 1960)

\section{Foliation}

Foliation in Gulkana Glacier is a three-dimensional layered structure with individual layers from 0.5 to $150 \mathrm{~cm}$. thick arranged in various patterns. Folia may be identified individually by variations in ice types. In Gulkana Glacier three principle ice types occur: white bubbly ice, bluish clear ice and fine-grained ice.

White bubbly ice appears milky to nearly transparent, depending on the concentration of air bubbles. Most bubbles are spheroidal with a suggestion in some areas of random elongation. This ice variety usually forms the thickest foliation layers and comprises 80 per cent of the ice exposed in the glacier. 


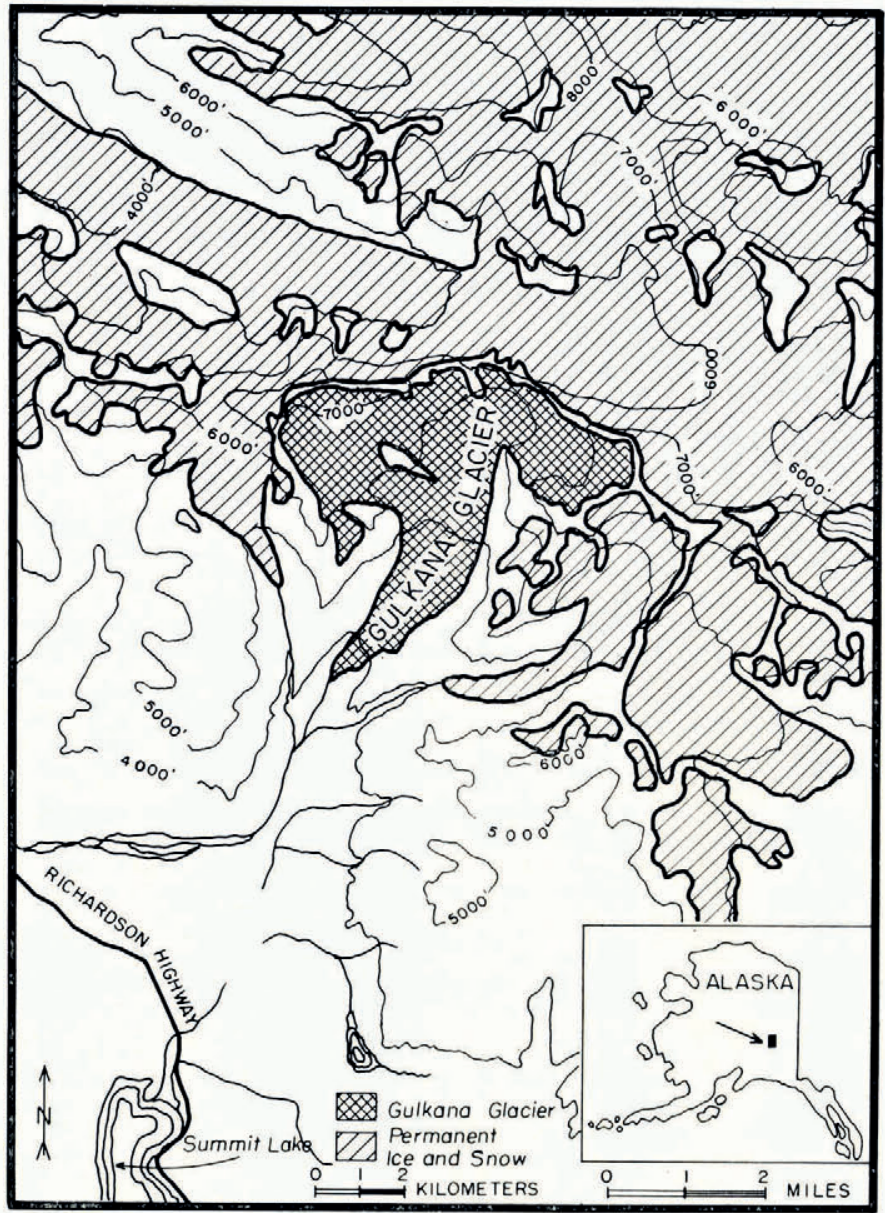

Fig. 2. Index map, Gulkana Glacier. Contour interval 1,ooo ft. (305 m.). (Based on U.S. Geological Survey topographic maps, Mount Hayes $A-3,1954$ and $B-3,1955)$

Bluish clear ice is transparent, generally has no bubbles and appears brilliant blue in direct sunlight. Not more than 15 per cent of the ice exposed in Gulkana Glacier is of this variety.

Fine-grained ice is identified most easily by its weathering characteristics. On the glacier surface where weathering is pronounced, fine-grained ice disaggregates leaving a deposit closely resembling firn. This weathered or disaggregated zone is about $8 \mathrm{~cm}$. thick and beneath it the ice may appear similar either to bluish clear ice or to white bubbly ice. However, the bubbles are relatively smaller than those of the normal white bubbly ice. Fine-grained ice constitutes less than 5 per cent of the ice exposed on Gulkana Glacier.

Alternation of white bubbly ice and bluish clear ice layers is predominant. Layers distinguished by variations of bubble concentration within white bubbly ice are less abundant. Allen and others (1960) have suggested that this be called bubble-segregation foliation. Fine-grained ice plays a relatively minor role in forming foliation, though thin layers less than $4 \mathrm{~cm}$. thick are intercalated between layers of other ice types.

The intensity or concentration of folia in a certain area is subdivided into strong, moderate or weak foliation. This is measured quantitatively by observing the number of visible layers of 


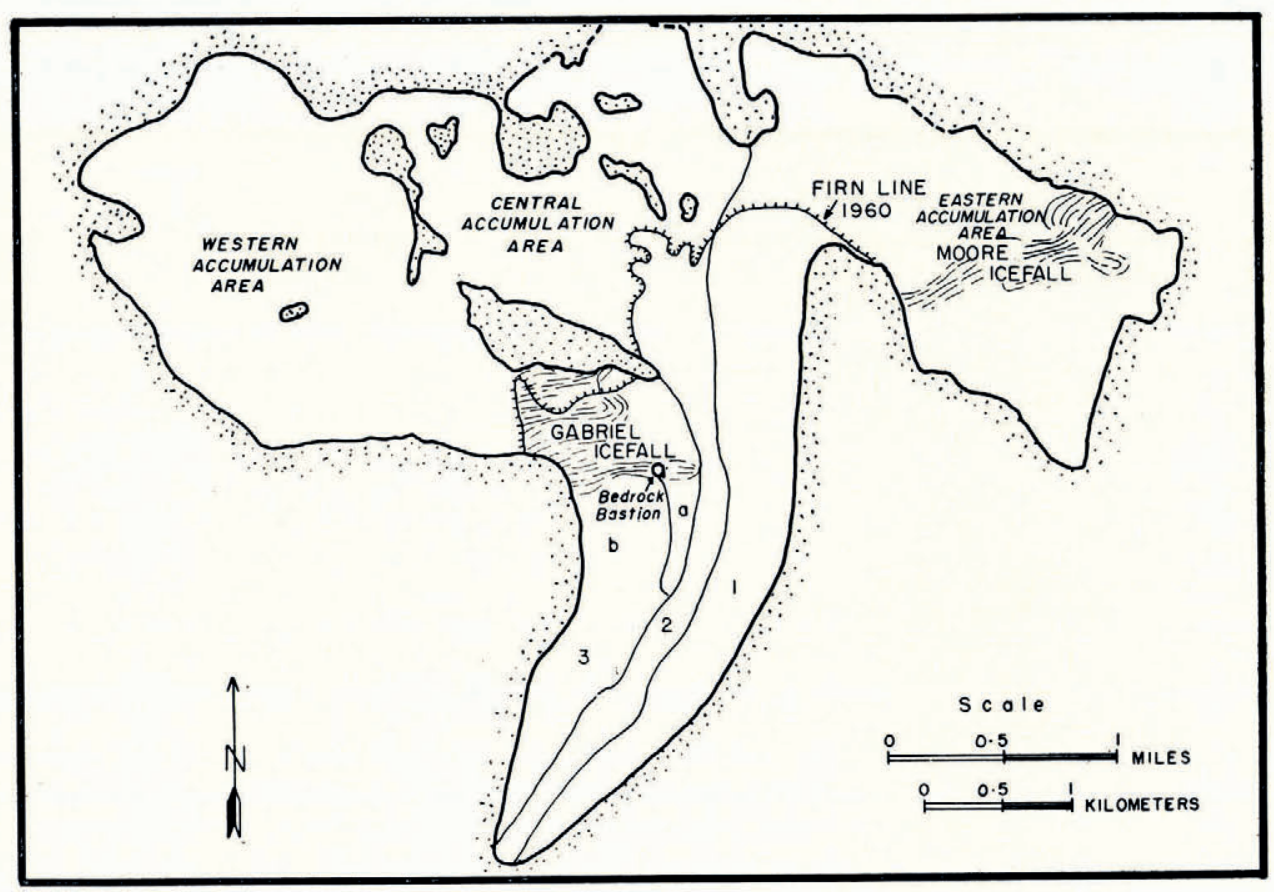

Fig. 3. Principal ice streams, accumulation areas, major ice falls and the 1960 firn line of Gulkana Glacier. (Base from uncontrolled mosaic. Photographs by U.S. Navy, 1957)

Table I. Dimensions of Ice Streams of Gulkana Glacier (Based on $1: 2,000$ topographic map constructed by the writer)

\begin{tabular}{|c|c|c|c|c|c|c|}
\hline & \multicolumn{3}{|c|}{$\begin{array}{l}\text { Length } \\
\mathrm{km} .\end{array}$} & \multicolumn{2}{|c|}{$\begin{array}{c}\text { Average width } \\
\mathrm{km} .\end{array}$} & \multirow{2}{*}{$\begin{array}{c}\text { Maximum } \\
\text { altitude } \\
\text { of } \\
\text { firn line } \\
1960 \\
\mathrm{~m} .\end{array}$} \\
\hline & $\begin{array}{l}\text { Above } \\
\text { firn } \\
\text { line }\end{array}$ & $\begin{array}{l}\text { Below } \\
\text { firn } \\
\text { line }\end{array}$ & Total & $\begin{array}{l}\text { Above } \\
\text { firn } \\
\text { line }\end{array}$ & $\begin{array}{l}\text { Below } \\
\text { firn } \\
\text { line }\end{array}$ & \\
\hline Ice stream I & $3 \cdot 2$ & $6 \cdot 0$ & $9 \cdot 2$ & I $\cdot 4$ & $0 \cdot 55$ & 1,768 \\
\hline Ice stream 2 & $2 \cdot 2$ & $5 \cdot 2$ & $7 \cdot 4$ & $2 \cdot 0$ & 0.25 & $1,75^{\circ}$ \\
\hline Ice stream $3 a$ & - & $I \cdot I$ & $\mathrm{I} \cdot \mathrm{I}$ & - & $0 \cdot 16$ & - \\
\hline Ice stream $3 \mathrm{~b}$ & $3 \cdot 2$ & $4 \cdot 0$ & $7 \cdot 2$ & I $\cdot 3$ & o. 59 & I, 768 \\
\hline
\end{tabular}

folia in one area in relation to another. Meier's (1960) definitions for each kind are adopted with some modifications.

On Gulkana Glacier strong foliation is represented by layers which are clearly visible both on weathered and fresh surfaces. Generally, the folia are layers of bluish clear ice up to $5 \mathrm{~cm}$. thick which alternate with layers of white bubbly ice about $10 \mathrm{~cm}$. thick. Only a few layers of fine-grained ice and bubble-segregation layers are present. Layers of bluish ice constitute as much as 35 per cent of the total ice appearing in strong foliation areas.

Moderate foliation is well-defined on weathered surfaces but it may be difficult to detect on fresh surfaces. The layers of white bubbly ice are up to $30 \mathrm{~cm}$. thick, whereas the bluish clear ice layers are $5 \mathrm{~cm}$. thick, as they are in the areas of strong foliation. Bubble-segregation layers increase in number due to the greater amount of white bubbly ice available. Thus, the relative amounts of fine-grained ice and of bluish clear ice layers are less than in areas of strong foliation. Bluish clear ice constitutes about 15 to 20 per cent of the total ice. 
Weak foliation can be observed on both weathered and fresh surfaces but only after careful inspection. Layers of white bubbly ice are as thick as $15^{\circ} \mathrm{cm}$. Layers of bluish clear ice are generally thicker (the majority is about $5 \mathrm{~cm}$.) than those found in strong and moderate foliation areas but there are fewer layers present and therefore bluish clear ice comprises only about 5 per cent of the total ice observed. Minor amounts of fine-grained ice and bubblesegregation layers are present.

\section{Foliation Pattern}

By studying the foliation pattern and the foliation intensity (Figs. 4 and 5) several conclusions can be drawn:

(I) The foliation increases in intensity and is parallel or sub-parallel to the longitudinal dimension of the glacier near the glacier margins, next to a bedrock bastion and near the plane where two ice streams flow adjacent to one another. The majority of dips are between $80^{\circ}$ and $90^{\circ}$.

(2) An arcuate (or semi-arcuate) foliation pattern with foliation intensity usually weak or moderate, develops below ice falls, as in ice streams $\mathrm{I}$ and $3 \mathrm{~b}$. Dips are towards the concave side of the arcs, varying between $10^{\circ}$ and $90^{\circ}$, decreasing down-glacier, suggesting that the structures may be "spoon-shaped". In other words, the dip is less steep where the ice thins away from the glacier margins, indicating that the folia may be horizontal near the central part of the base of the glacier.

Similar arcuate patterns have been observed below ice falls in other glaciers, such as Pasterze Gletscher, Austria (Untersteiner, I955), Blue Glacier, Washington (Allen and others, r960) and Fox Glacier, New Zealand (Gunn, r964). Longitudinal foliation has been noted on the above glaciers (with the exception of Fox Glacier) as well as on Saskatchewan Glacier, Alberta (Meier, 1960) and Burroughs Glacier, Alaska (Taylor, I963).

\section{OrIGIN}

Most workers agree that foliation is a secondary structure resulting from the deformation of ice during flow. For the most part foliation does not originate where it is observed, because most surface ice of a glacier is under a nearly stress-free condition (Nye, 1952).

It appears that longitudinal foliation forms in areas with strong compression and shear, such as near the glacier margin, in the areas where ice streams unite or where ice has to pass around an obstruction such as a bedrock bastion. In each case, obstructions initiate "drag", causing differential flow velocity which results in shear along discrete planes and the formation of the individual folia. The foliation is accentuated where the shear strain is the greatest. Examples of each situation are present in Gulkana Glacier (Figs. 4 and 5).

Apparently, vertical transverse foliation is formed at the base of an ice fall by strong longitudinal compression in the ice, which is the result of the sudden decrease in flow velocity caused by a decrease in gradient of the bedrock. Gunn (1964) has noted on the Fox Glacier that where the flow rate decreases most rapidly transverse foliation is well-developed. Preexisting structures (foliation and closed crevasses which have passed through an ice fall) may survive the strong longitudinal stresses at the base of an ice fall and contribute significantly to the final foliation pattern.

Following Nye's (1952) theories of glacier flow and taking into account the foliation pattern displayed on Gulkana Glacier (assuming transverse foliation is passive once it has formed), one can speculate that the individual ice streams are flowing as independent units for much of the length of the glacier. In other words, the pattern that the transverse foliation displays during flow is used in roughly predicting qualitatively the relative flow velocity across the surface of the glacier. Although the writer does not have the flow data at hand, the idea of independent flow units was substantiated by flow-velocity data on Gulkana Glacier collected by G. Moores in I96r (personal communication from T. L. Péwé). However, 


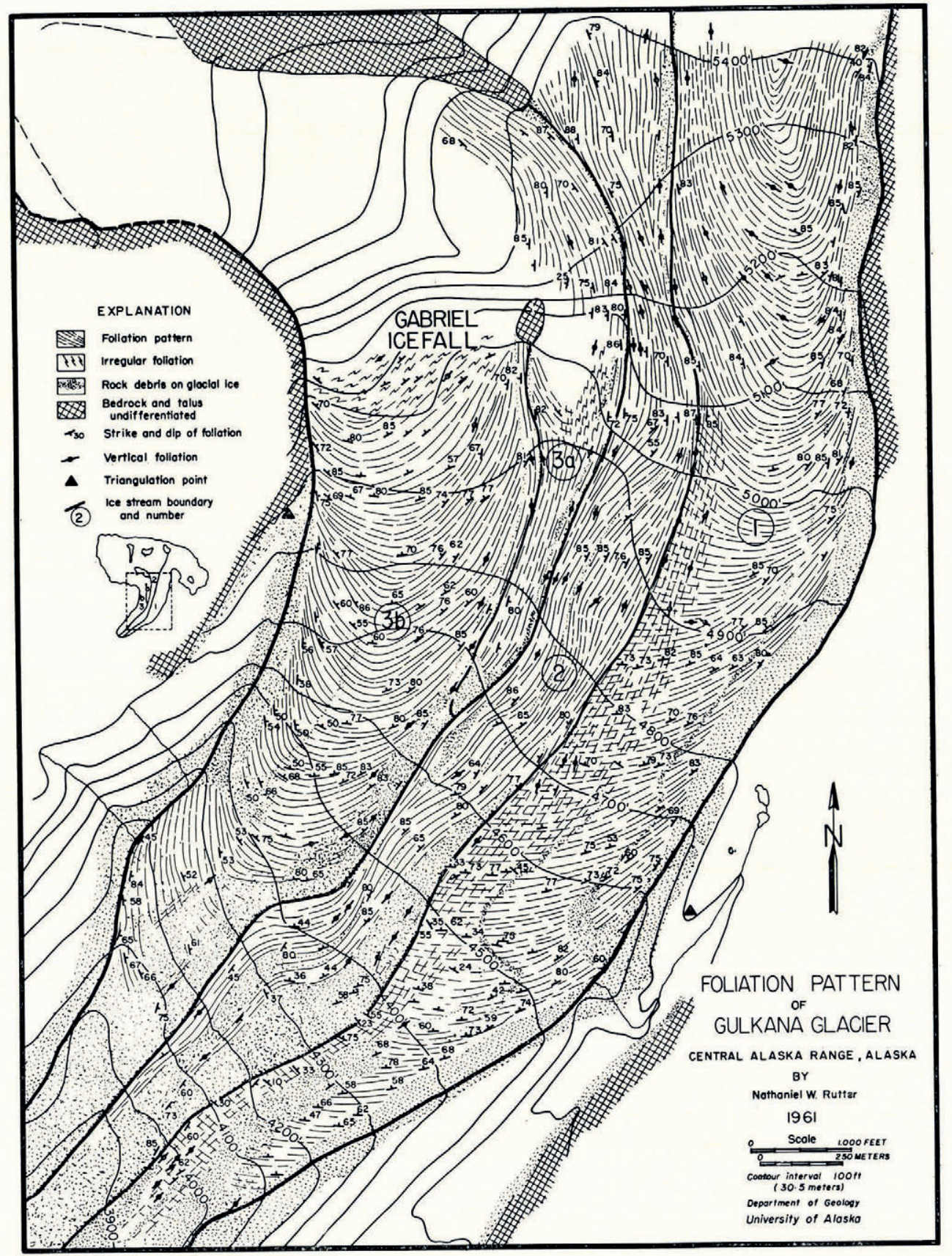

Fig. 4. Foliation pattern displayed on Gulkana Glacier. Attitude of foliation was measured with a Brunton compass. The positions of the measurements were located by taking bearings on known points and plotting them on a $1: 2$,ooo topographic map constructed by plane-table methods by the writer. The anomalous attitudes shown are minor variations within the regional trend of layers 


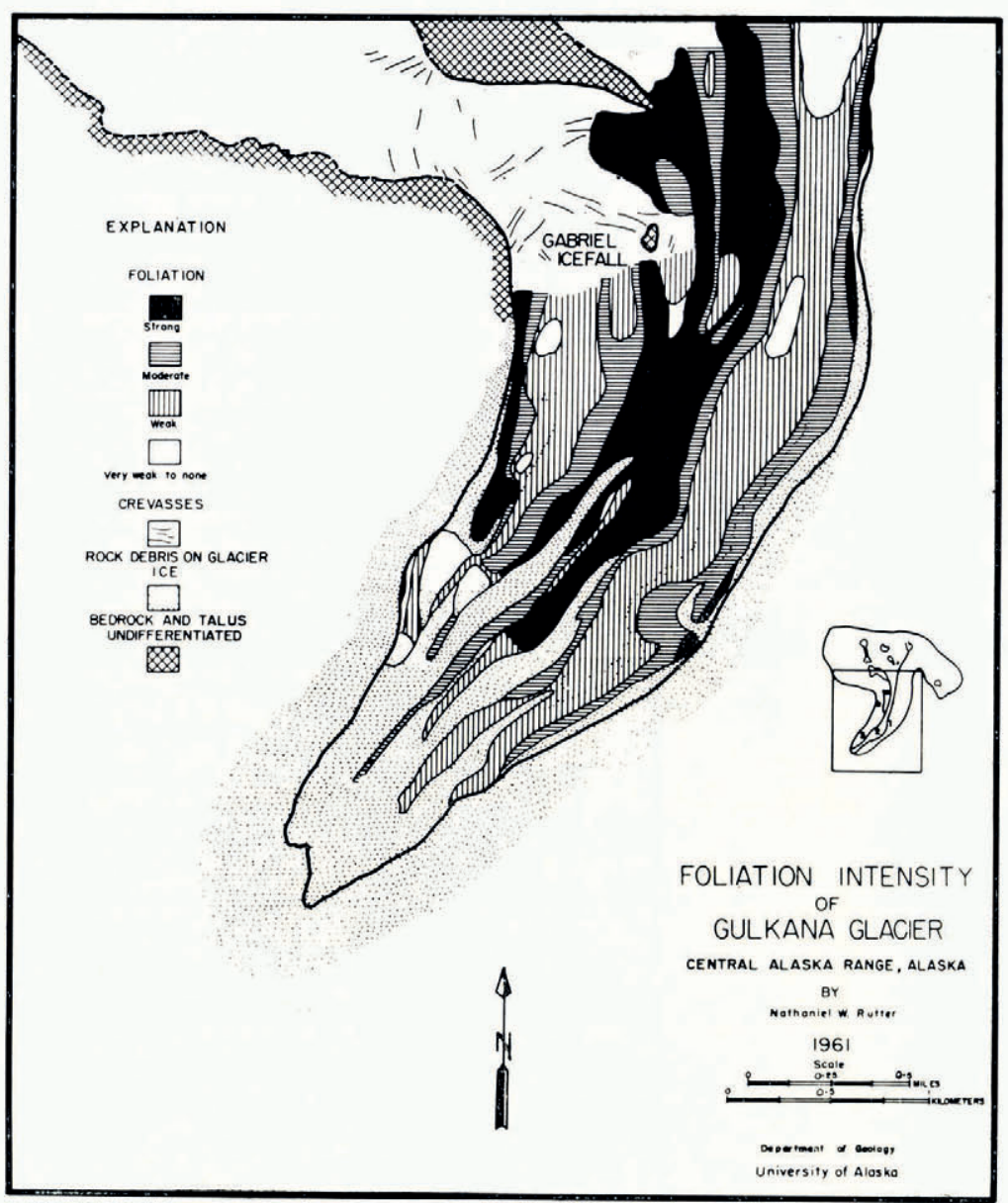

Fig. 5. Foliation intensity on the lower part of Gulkana Glacier. See text for explanation of strong, moderate and weak foliation intensity

P. V. Sellmann (I96I) has noted that measurement of flow velocity taken near the terminus of Gulkana Glacier in 1960 indicates that the glacier is flowing as a unit there. The writer believes that the above results help to explain the semi-arcuate pattern in ice stream I (Fig. 4). Assuming ice stream 2 flows relatively slower than the other streams, it is suggested that ice streams $\mathrm{I}$ and 2 combine and flow as a single unit somewhere south-east of the rock bastion which divides ice stream 3 into two components. This combination tends to shift the maximum flow velocity in this area towards the center of the glacier, "bending" the west limbs of the individual arcs down-glacier and forming the semi-arcuate pattern. Prior to or during the union of the two ice streams, the cross-cutting longitudinal foliation was probably developed. Towards the terminus of the glacier, ice stream 3 b combines with the other ice streams and thus the glacier flows as a unit. However, since the glacier is covered with debris in this area, it is not possible to determine whether the eastern limbs of the arcs in ice stream $3 \mathrm{~b}$ have been shifted into semi-arcs. 


\section{Acknowledgements}

Research on Gulkana Glacier was carried out during the summer of ig6o. Funds were provided by the National Science Foundation through a grant to Dr. T. L. Péwé, Department of Geology, University of Alaska. The writer wishes to thank Dr. Péwé for his encouragement and guidance during the research. This paper represents a modified part of a dissertation submitted to the University of Alaska in partial fulfillment of the requirements for an M.S. degree.

Messrs K. Burnes, P. V. Sellmann and W. Grothe provided valuable assistance in obtaining field data, which is gratefully acknowledged. Field and scientific equipment was generously loaned by the U.S. Army, Fort Greely, Alaska; U.S. Army Cold Regions Research and Engineering Laboratory, Hanover, New Hampshire; University of Alaska; and U.S. Geological Survey.

The writer extends his appreciation to Dr. T. L. Péwé, Dr. R. P. Sharp, California Institute of Technology, Dr. A. J. Broscoe and Dr. J. F. Lerbekmo, University of Alberta, for critically reviewing the manuscript. Their advice and comments were invaluable.

MS. received 5 January 1965

\section{REFERENCES}

Allen, C. R., and others. 1960. Structure of the lower Blue Glacier, Washington, by C. R. Allen, W. B. Kamb, M. F. Meier and R. P. Sharp. Journal of Geology, Vol. 68, No. 6, p. 60I-25.

Gunn, B. M. 1964. Flow rates and secondary structures of Fox and Franz Josef Glaciers, New Zealand. Journal of Glaciology, Vol. 5, No. 38, p. 173-90.

Meier, M. F. ig6o. Mode of flow of Saskatchewan Glacier, Alberta, Canada. U.S. Geological Survey. Professional Paper 351 .

Nye, J. F. 1952. The mechanics of glacier flow. Fournal of Glaciology, Vol. 2, No. 12, p. 82-93.

Sellmann, P. V. ig6r. Preliminary report on the ablation and flow, Gulkana Glacier, central Alaska Range, Alaska. Geological Society of America. Special Papers, No. 68, p. 120.

Taylor, L. D. I963. Structure and fabric on the Burroughs Glacier, south-east Alaska. Fournal of Glaciology, Vol. 4, No. $3^{6, \text { p. }} 73^{1-52}$.

Untersteiner, N. 1955. Some observations on the banding of glacier ice. Journal of Glaciology, Vol. 2 , No. 17. p. 502-06. 